СПИСОК ВИКОРИСТАНИХ ДЖЕРЕЛ:

1. Тер-Минасова С.Г. Язык и межкультурная коммуникация. Москва : Слово Slovo, 2000. 624 c.

2. Полат Е.С, Петров А.Е. Дистанционное обучение. Каким ему быть? Педагогика. 1999. № 7. С. $29-34$.

3. Дьюи Д. Психология и педагогика мышления / Пер. с англ. Н.М. Никольской. Москва : Совершенство, 1997. 208 c.

4. Щенников С.А. Открытое дистанционное образование. Москва : Наука, 2002., 174 с.

УДК 81'367.4

DOI https://doi.org/10.32782/tps2663-4880/2019.12.24

\title{
COMPUTER GAMES IN THE LIGHT OF CONSTRUCTIONS
}

\section{КОМП'ЮТЕРНІ ІГРИ КРІЗЬ ПРИЗМУ КОНСТРУКЦЙ}

Talavira N.M., orcid.org/0000-0002-5600-5893

Associate Professor at the Chair of Germanic languages and Methods of Teaching Foreign Languages Mykola Gogol State University of Nizhyn

The article suggests a typology of constructions denoting computer games in modern English online news discourse.

Constructions are viewed as a pairing of form, meaning and function, stored in mind due to frequent usage. In the vein of syntagmatic relations constructions are classified into immediate, comprising two components, modified, which transform the immediate ones due to adjectives or pronouns, and extended that combine several modified ones.

The constructions under analysis are classified into those naming game-participants and types of games. All constructions about participants are divided into those, who are involved in game making process and those, who play already created games. We have singled out 6 immediate constructions that denote individuals, who are engaged in game developing which are modified by adjectives to denote experience, talents and age of game creators. These constructions enter extended constructions indicating professional duties of game-developers, their financial state and cooperation with players. In terms of constructions that represent game players, we have two immediate constructions which are modified by adjectives and pronouns to reflect gamers' experience, their personal characteristics, and the choice of played games or group work. As for extended constructions, they denote typical activity of gamers, their multitasking performance or prohibitions they experience. The group of constructions is further subdivided into those reflecting the used gadget; the number of participants; the performed task. Extended constructions that are used to describe games are focused on influence on players, their mental activity or contribution to their popularity.

Key words: construction, immediate construction, modified construction, extended construction, computer game.

У статті пропонується типологія конструкцій на позначення комп'ютерних ігор у сучасному дискурсі онлайн-новин.

Конструкції потрактовуються як поєднання форми, змісту та функції і включають морфеми, слова, ідіоми, частково лексично заповнені зразки та повністю узагальнені мовні одиниці. Конструкції вкоренилися у свідомості людей та зберігаються у готовому вигляді завдяки регулярному використанню в мовленні. Парадигматично аналізовані одиниці поділяються на конкретні вирази, лексикалізовані та граматикалізовані конструкції. 3 огляду на синтагматичні відношення конструкції класифікуємо на безпосередні, які є поєднанням двох компонентів, модифіковані, що трансформують безпосередні за рахунок прикметників, іменників з прийменниками або прислівників, та розширені, утворені декількома безпосередніми.

Тематично конструкції позначають учасників та види гри. Всі конструкції на позначення учасників поділяємо на ті, що називають осіб, задіяних у створенні комп'ютерних ігор, та гравців. Шість безпосередніх конструкцій на позначення розробників ігор можуть бути модифіковані прикметниками для акцентуації досвіду, віку або таланту творців ігор, тоді як розширені конструкції вказують на професійні обов'язки, фінансовий стан та співробітництво з гравцями. Дві безпосередні конструкції, що репрезентують геймерів, трансформуються за допомогою прикметників та займенників для виокремлення особистих характеристик гравців, їхньої групової діяльності або обраних ними ігор. Розширені конструкції іменують типову діяльність гравців, багатозадачність їхньої ігрової активності або заборони, яким вона підлягає.

Конструкції на позначення ігор вказують на пристрій, що використовується, кількість учасників та ключове завдання. Розширені конструкції відображають вплив ігор на геймерів, їхню ментальну активність або популярність завдяки їхньому захопленню.

Ключові слова: конструкція, безпосередня конструкція, модифікована конструкція, розширена конструкція, комп'ютерна гра.

Setting the problem. Computer games have become widespread in our society when players spend hours glued to the screen to enjoy the thrill of winning or suffer the despair of losing. Computer games are a set of parts that interrelate to form a complex whole [19, c. 55], they have rules and chance, 
and they are played - the player plots events and interacts with objects in the game world [4, c. 85]. Games are no longer just children's activity: the majority of players are now adults, and the market is growing. The visual style of games has become increasingly sophisticated, and the game-play itself is becoming ever more challenging. They may be criticized and condemned for the negative influence on young people [20;3], defined as a new form of art or cultural form $[4$, c. 4]. Still, the various features and forms of games are increasingly influencing a whole range of other media, from films and television to books and toys. Thus, they are studied from various perspectives [see: 4].

In our cases, we focus on the linguistic aspect. As is known, objective or imagined reality is reflected by various words, word-combinations, phraseological units and sentences as language is considered to be a means of human reasoning and cognition $[1$, c. 2]. A new linguistic unit singled out by modern researchers is constructions. They are distinguished as non-predictable ready-made units $[8$, c. 6$]$.

Analysis of previous works. Constructions have been researched by scholars from different perspectives. Researchers investigate characteristics of constructions: their productivity [8, c. 98], degrees of schematicity [17, c. 191], their crosslinguistic similarities [5, c. 157]. In the vein of types of constructions, linguists have studied sentence-level constructions [13, c. 219], variation of the units under analysis $[12$, c. $155 ; 16$, c. 2] and prefabricated units [6, c. 203]. However, little attention has been paid to the topics that constructions denote. Thus, the aim of this study is analysis and classification of constructions that represent different aspects of computer games in English article of the online news site www.bbc. com. To achieve this aim we have to solve the following tasks: to specify the notion of constructions and their peculiarities; to classify constructions in accord with the denoted aspects of computer games; to analyze immediate constructions that represent various aspects of gaming and extended constructions they enter.

Constructions are viewed as certain pairings of form, meaning and function [14, c. 5], including morphemes, words, idioms, partially lexically filled and fully general linguistic patterns [9, c. 669; 15 , c. 14]. They are prefabricated linguistic units which need only minimal modification to be used in communication [6, c. 203]. Constructions are entrenched in human's mind [7, c. 28] and are stored in a ready-made form $[9$, c. 699$]$ due to a high frequency of repetition $[14$, c. $5 ; 23$, c. 187].
Though constructions are units with a fixed structure they allow some transformations due to the slots available in their form, i.e. participant roles associated with a construction or a verb [13, c. 49], varying from one use to the next [14, c. 39].

Constructions are threated from two perspectives: paradigmatic, concerning different levels of meaning generalization [18, c. 173], and syntagmatic, focusing on their linear expansion [21, c. 102]. Paradigmatically, constructions are divided into itembased, lexicalized and grammaticalized [22, c. 62]. Even though potentially decomposable into constituents item-based constructions are stored and used as single units, e.g. You keep out of this. Lexicalized constructions are relatively abstract, e.g. Let's $X$ it, There's a $X$. Grammaticalized constructions are highly abstract entities based on commonalities in the forms and functions of a whole host of different specific expressions, e.g. negation constructions; motion construction [22, c. 62].

From the syntagmatic viewpoint, on the criterion of absence or presence of the context, constructions are divided into immediate, modified and extended [18, c. 173]. Immediate constructions are word combinations with the dependent units either on the left or on the right [ibid]. There are constructions with dependent elements joined on the left, e.g. designer of a game, or on the right, e.g. game designing. Modified constructions admit additional elements expressed by adjectives, e.g. a talented game designer, or pronouns, e.g. his single-player game [21, c. 102]. Extended constructions include the immediate constructions into an utterance or a text [11, c. 1]. And when we need to analyze extended constructions the primary attention is devoted to the context in which a construction is used, e.g. Most video gamers play in the company of friends (13.03.2017). In this sentence the immediate variant video gamers is modified by the pronoun most and extended by the element play in a company of friends.

A theme-based division is one more method to classify constructions due to the described topic. To name all possible topics is difficult on condition of their diversity.

There are several types of constructions that are mainly used in articles about computer games i.e. a game that is played on a computer, in which the pictures that appear on the screen are controlled by pressing keys or moving a joystick [2]. Having worked with numerous articles connected with games and game developing, we have focused on two main types of constructions. They are:

- game participants engaged in gaming process;

- kinds of games. 
Constructions denoting game participants include game-developers and gamers.

According to the different aspects of game making process, we have singled out 6 immediate constructions that denote game-developers: a game maker, a game designer, a voice artist, a video artist, a product manager and a community manager. They can be modified by adjectives indicating their features: experience, e.g. aspiring and mature game makers (27.08.2015); talents, e.g. creative video artists (17.04.2018); age, e.g. a young game designer (21.10.2016).

Immediate constructions are extended by verbs or verbal phrases, naming professional duties of gamedevelopers, e.g. game designers gather to grow their ideas (17.05.2017); video game designers have created a game with a difference (16.09.2015); financial state, e.g. video game actors don th get any extra payments (11.03.2018), make their living as voiceover artists (21.10.2016); cooperation with players, e.g. tweeted game designer Mike Bithell (24.10.2016), game designer Arran Langmead reaches a global audience (30.02.18); supervision, e.g. product managers help co-ordinate the overall direction of the game (19.04.2019), game designers make you more powerful (18.02.2016), community managers handle player feedback (27.08.2015); by prepositional phrases to specify their duties, e.g. a game designer of PC-based puzzle games (21.07.2015).

Constructions denoting gamers - be a player and to be a gamer - have equal meaning and can be used interchangeably. There are numerous modified constructions where adjectives denote players' experience, e.g. older players (24.07.2017), seasoned players (11.03.2017), a professional gamer (19.08.2018); their personal characteristics, e.g. an enthusiastic gamer (08.12.2018), a keen gamer (11.03.2017), an avid gamer (26.04.2014); the choice of played games, e.g. video gamers (05.10.2015), a cyber-augmented gamer (20.09.2014), mobile gamer (17.08.2016); group work of players, e.g. a volunteer army of gamers, a huge community of gamers (11.03.2017).

Entering extended constructions they combine with verbs or verbal phrases denoting typical activity, e.g. a young gamer who has not played on the original console (29.11.2018), a player will win the game (08.10.2017), players can spend huge sums (12.02.2017); their multitasking performance, e.g. a player solves a puzzle (21.07.2015); or prohibitions, e.g. gamers will be banned from playing (06.11.2019).

Immediate constructions naming kinds of games reflect the necessary gadgets for playing, the number of players, the form of playing and tasks to be solved in a game.

As for types of gadgets there are three constructions: a computer game, a video game and a mobile game. The modified units underscore characteristics of games, e.g. a visually rich desktop-based game (08.10.2017), an interesting computer game (21.07.2015). Both immediate constructions a computer game and a video game enter extended constructions with units having similar meaning, i.e. ability to influence a player positively, e.g. computer games can make us better people (21.07.2015), playing more computer games is good (08.10.2017), video games can help people see better, learn more quickly, develop greater mental focus (26.08.2013); negatively, e.g. playing video games can lead to brain changes (24.10.2016); or both ways, e.g. computer games can either cause problems or be beneficial (26.08.2013). The immediate construction a mobile game enters, in addition, extended constructions indicating portability of mobile games, e.g. mobile games can be enjoyed anywhere (14.08.2016).

When focusing on game-constructions reflecting the number of participants we can pinpoint two units: single-player games, i.e. a game designed for one player only, and multiplayer games, i.e. a game that involves several players. These two immediate constructions enter extended constructions that denote player's activity, e.g. it is better to play single-player game (18.02.2016), people engaged in multiplayer-game (21.07.2015), play multi-player first-shooter (14.08.2016).

According to the form of play, there are firstperson games and third-person games, depending respectively on whether gamer's movements provide a view of what an actual person would see and do in the game or a player has a personage, which represents him in a game, and can be seen on a screen and whose visual characteristics can be changed [10]. Extended constructions with both immediate components underscore benefits of games, e.g. a third-person fantasy adventure role-playing game helped gamers to enrich their imagination (21.10.2016), those playing a first-person shooter saw an improvement in their contrast sensitivity function (13.03.2017).

Games can be also classified according to the type of tasks: action games, puzzle games, role-play games. The extended constructions denote mental activity, e.g. fast action games require the player constantly to switch their attention (16.09.2015), action games improving people's focus (14.08.2016), puzzle gamers appear to have better focus (08.10.2017), may seem like just another brain-teasing puzzle game (21.07.2015); indicate contribution to popularity, e.g. 
famous for its 15-year-old RuneScape fantasy roleplaying game (04.10.2016).

To conclude, constructions verbalizing computer games fall into two groups depending on the denoted aspect: game-participants and types of games. All constructions about participants are classified into those, who are involved in game making process and those, who play already created games. We have singled out 6 immediate constructions that denote people, who are engaged in game developing which are modified by adjectives to denote experience, talents and age of game creators. These constructions enter extended constructions indicating professional duties of gamedevelopers, their financial state and cooperation with players. In terms of constructions that underscore game players, we have two immediate constructions which are modified by adjectives and pronouns to reflect gamers' experience, their personal character- istics, the choice of played games or group work. As for extended constructions, they denote typical activity of gamers, their multitasking performance or prohibitions they experience. The group of constructions that characterize games is rather diverse. For this reason we have grouped kinds of games according to the gadget that is used while playing. According to this criterion, gaming-constructions may denote computer, video and mobile games. Depending on the number of participants games are grouped into single-player games and multiplayer ones. As for the task that lies in the core, games may be classified into action, puzzle and role-play ones. Extended constructions that are used to describe games are focused on influence on players, their mental activity or contribution to their popularity. Further research in this realm may be connected with differentiating other thematic groups of constructions.

\section{REFERENCES:}

1. Гуцалюк О.Н. Типы и функции номинаций персонажа : автореф. дис. ... канд. филлол. наук : 10.02.01. Москва, 2010. 20 с.

2. Cambridge Dictionary. URL: http://dictionary.cambridge.org/ru (accessed 08.11.2019).

3. Computer Games and Technical Communication : Critical Methods and Applications at the Intersection / J. deWinter et al ; ed. by J. deWinter, R. M. Moeller. Farnham : Ashgate Publishing, Ltd., 2014. 336 p.

4. Computer Games : Text, Narrative and Play / D. Carr et al. New York : John Wiley \& Sons, 2014. 224 p.

5. Croft W. Constructions and generalizations. Cognitive Linguistics. 2009. Vol. 20, № 1. P. 157-165.

6. Dąbrowska E. Language, Mind and Brain. Edinburgh : Edinburgh University Press, 2010. 262 p.

7. Dirven R., Ruiz de Mendoza Ibáñez F. J. Looking back at 30 years of Cognitive Linguistics. Cognitive Linguistics in Action. From Theory to Application and Back. Berlin, New York : Mouton de Gruyter. 2010. P. 13-70.

8. Eckhoff H.M. Old Russian possessive constructions : A construction grammar approach. Boston : Mouton de Gruyter, 2011. 340 p.

9. Evans V. Green M. Cognitive Linguistics : An Introduction. Edinburgh : Edinburgh University Press, 2006.829 p.

10. First Person Shooter (FPS). URL: https://www.techopedia.com/definition/241/first-person-shooter-fps (accessed 08.11.2019).

11. Franceschi D. The cum-construction in present-day English. Italian Journal of Linguistics. 2013. № 25. P. 1-23.

12. Gisborne N. Constructions, word grammar, and grammaticalization. Cognitive Linguistics. 2011. Vol. 22, № 1. P. 155-182.

13. Goldberg A.E. Constructions : A Construction Grammar Approach to Argument Structure. Chicago, London : Chicago University Press, 1995. 265 p.

14. Goldberg A.E. Construction at Work : The Nature of Generalizations in Language. Oxford : Oxford University Press, 2006. 280 p.

15. Hilpert M. Germanic future constructions : A usage-based approach to language change. Amsterdam : John Benjamins Publishing. 2008. 205 p.

16. Hoffmann T., Trousdale G. Variation, change, and constructions in English. Cognitive Linguistics. 2011. Vol. 22,

№ 1. P. 1-23.

17. Lieven E. Developing constructions. Cognitive Linguistics. 2009. Vol. 20, № 1. P. 191-199.

18. Potapenko S.I. Constructions in English : from paradigmatic to syntagmatic relations. Література і культура Полісся. 2017. Вип. 89. С. 172-180.

19. Salen K., Zimmerman E. Rules of Play : Game Design Fundamentals. Cambridge : The MIT Press. 2003. 688 p.

20. Squire K. Cultural Framing of Computer / Video Games. URL : http://www.gamestudies.org/0102/squire/ (accessed 08.11.2019).

21. Talavira N. English orientating constructions denoting location : classification and article use. Lingua Posnaniensis. 2017. Vol. 59, Issue 2. P. 101-120.

22. Tomasello M. First steps toward a usage-based theory of language acquisition. Cognitive Linguistics. 2000. Vol. 11, №1/2. P. 61-82.

23. Zeschel A. What's (in) a construction? New Directions in Cognitive Linguistics / ed. by V. Evans. Bangor : Bangor University Press, 2009. P. 185-200. 